\title{
Role of Heat-Treated Laterite on the Strengthening of Geopolymer Designed with Laterite as Solid Precursor
}

\author{
Raïssa Charlie Poudeu ${ }^{1}$, Cyprien Joel Ekani ${ }^{1}$, Chantale Njiomou Djangang ${ }^{1 *}$, Philippe Blanchart ${ }^{2}$ \\ ${ }^{1}$ Department of Inorganic Chemistry, University of Yaounde I, POB 812 Yaounde, Cameroon \\ ${ }^{2}$ Institute of Research for Ceramics - IRCER, 12 rue Atlantis 87068 Limoges, France
}

Corresponding Author Email: cndjangang@uy1.uninet.cm

https://doi.org/10.18280/acsm.430601

Received: 12 July 2019

Accepted: 26 November 2019

\section{Keywords:}

laterite, geopolymer, heat-treatment, strengthening, network structure, construction material

\begin{abstract}
This paper aims to develop a low-cost, green construction material for low-income house builders. A series of geopolymer samples were prepared by partially substituting the Cameroonian lateritic soil (LS) with different quantities of heat-treated laterite (20 50 wt. \%). The chemical composition of the LS was determined through inductively coupled plasma spectroscopy (ICP). The specimens were subjected to thermogravimetric and differential thermal analyses (TGA/DTA), X-ray diffractometry (XRD) and Fourier Transform Infrared Spectroscopy (FTIR). In addition, the compressive strength of dry and wet specimens was measured with a hydroelectric device. The results show that the geo-polymerization and properties like setting time and mechanical strength of the samples were improved through the combined action of the raw LS and the laterite treated at $500-600^{\circ} \mathrm{C}$; the crystallized particles from non-clayed minerals and from aggregates of kaolinite also contribute to strength of the samples; crystalline phases formed a tridimensional skeleton in the microstructure of the geopolymer. The research provides a promising composite that can serve as a low-cost construction material with reduced environmental impact.
\end{abstract}

\section{INTRODUCTION}

Laterite belongs to the mineral group of alumino-silicates. It contains the clay mineral kaolinite that is associated to variable contents of sesquioxides of iron and/or aluminium. The dominant process of laterite formation is weathering and leaching. It leads to the increase of iron and aluminium hydroxides contents that are released during the alteration of various rocks under the hot rainfall. Kaolinite crystallizes from aqueous solutions when aluminum ions coexist with enough content of silicon. Besides, gibbsite is found when a very low concentration of dissolved silicon results from a large drainage. Dissolved iron is very reactive and forms either iron (II) hydroxides (such as goethite) or iron (III) oxides (such as hematite). Kaolinite, gibbsite, goethite and hematite are associated minerals that coexist with the relicts of partially dissolved quartz. They are the major components of compact laterites that are mostly under the form of complex and heterogeneous compounds containing mainly $\mathrm{Fe}_{2} \mathrm{O}_{3}-\mathrm{Al}_{2} \mathrm{O}_{3}$ $\mathrm{SiO}_{2}-\mathrm{H}_{2} \mathrm{O}$ [1-3].

The need for affordable, safe and decent housings is one of the greatest impediments to self-fulfillment in many countries. Soil and lateritic blocks are natural resources used in many African countries. They are extensively used to obtain cut blocs, compressed earth blocks, or adobe materials at a low cost. To provide a significant improvement of mechanical strength and durability [4], binders such as Portland cement can be added to soils and lateritic materials, but with a higher cost and a significant environmental impact.

Nowadays, geopolymers have emerged as one of the possible ecological binders with a reduced $\mathrm{CO}_{2}$ footprint [5-8]. Geopolymers are a class of composite materials containing a quasi-amorphous matrix phase, in which three dimensional aluminosilicates grains are distributed. The curing and hardening processes are achieved at ambient temperature or slightly higher. The hardening reactions occurs between aluminosilicate precursors and highly concentrated aqueous solutions of alkaline hydroxides and silicates [9-11].

Geopolymers have attracted interest in the last three decades. Many research papers on the synthesis of geopolymers have focused in the use of different aluminosilicates such as recycled industrial wastes [12, 13] metakaolin [14-17], meltquenched aluminosilicates [18], grinded mineral resources such as volcanic scoria $[19,20]$ and mixtures of two or more of these materials [21-23].

In addition to studies focused in raw materials, a limited number of investigations have been made on geopolymers based on laterite, despite the wide distribution of this resource throughout the world, and especially in Cameroon [24-27]. Laterite and lateritic soil constitute $33 \%$ of available mineral resources in tropical and subtropical zones of Africa, Australia, India, South-East Asia and South America. They are often found just below the surface of grasslands or forests $[9,11,28]$. In Cameroon, laterite and lateritic soil cover nearly $67 \%$ of the country surface [29, 30]. Consequently, laterite is available in huge quantity and at low cost. The environmental impact is relatively low in comparison to that of clays that are often mined on surface (detrimental to agriculture) or found in deeper enclosed sites (needs to remove the upper layers of rocks).

The aim of this study is to obtain construction materials at low cost and with a reduced environmental impact, for lowincome house builders. Studied geopolymers are composed of an as-mined Cameroonian laterite that react with an alkaline 
solution. To change the reaction process, the laterite is substituted by different quantities of heat-treated laterite (20$50 \mathrm{wt} . \%)$. Physical properties of materials during the setting process and microstructural observations were corelated to compressive strength to optimize the composition.

\section{MATERIALS AND METHODS}

\subsection{Materials}

The raw material is a lateritic soil from Ngoa-EkelleYaoundé (Center Region of Cameroon N05 $51^{\prime} 00$ '" E11 $\left.1^{\circ} 30^{\prime} 18^{\prime \prime}\right)$, which was dried at $60^{\circ} \mathrm{C}$, crushed and sieved at $63 \mu \mathrm{m}$ (named LN). Samples of LN were heated respectively at $500^{\circ} \mathrm{C}$ and $600^{\circ} \mathrm{C}$ (LN500 and LN600 respectively) for $4 \mathrm{~h}$ in an electric kiln (Nabertherm, Mod. LH 60/14) to reduce the crystallinity degree. A similar temperature interval was used in previous works to study the synthesis of geopolymers [31, 25].

A set of geopolymer samples was obtained with the laterite (LN) that was partially substituted by $20,30,40$ and $50 \mathrm{wt} . \%$ of heat-treated laterite. Mixtures compositions are reported in Table 1. The alkaline solution used for the activation of mixtures is composed of 50:50 Vol.\% of a sodium hydroxide solution ( $8 \mathrm{M}$ with $\mathrm{NaOH}$ pellets, $99 \%$ purity), mixed with an $8 \mathrm{M}$ sodium silicate with the formulae $26.45 \mathrm{SiO}_{2} 9.14 \mathrm{Na}_{2} \mathrm{O}$ $60 \mathrm{H}_{2} \mathrm{O}$. (26.45 wt. $\% \mathrm{SiO}_{2}, 9.14$ wt. $\% \mathrm{Na}_{2} \mathrm{O}$ and 60 wt. $\% \mathrm{H}_{2} \mathrm{O}$ ).

Table 1. Composition of mixtures of crude laterite (LN) and calcined laterite (L500 and L600)

\begin{tabular}{cc}
\hline $\begin{array}{c}\text { Wt.\% of crude laterite } \\
(\mathbf{L N})\end{array}$ & $\begin{array}{c}\text { Wt.\% of calcined laterite (L500 or } \\
\text { L600) }\end{array}$ \\
\hline 100 & 0 \\
\hline 80 & 20 \\
\hline 70 & 30 \\
\hline 60 & 40 \\
\hline 50 & 50 \\
\hline 40 & 60 \\
\hline 30 & 70 \\
\hline 20 & 80 \\
\hline
\end{tabular}

\subsection{Experimental methods}

The chemical composition of LN was determined by Inductively Coupled Plasma Spectroscopy (ICP). The degree of laterization (R) was calculated using Eq. (1) [32].

$$
R=\frac{\left[\mathrm{SiO}_{2}\right] / 60}{\left[\mathrm{Al}_{2} \mathrm{O}_{3}\right] / 102+\left[\mathrm{Fe}_{2} \mathrm{O}_{3}\right] / 160}
$$

Simultaneous thermogravimetric and differential thermal analyses (TGA/DTA) were carried out using a SETARAM equipment (Setsys 24 series) under air atmosphere. The specific surface areas of powders of LN, LN500 and LN600 were measured with a BET apparatus (Micromeritics TriStar II).

Activated paste samples were prepared by mixing the powders of Table 1 with the alkaline solution, maintaining a mass of solid $(\mathrm{g})$ ratio to the volume of solution $(\mathrm{mL})$ of 1.7 . The pastes were poured into cylindrical PVC molds and compacted during 5 minutes under vibrations, to remove entrapped air bubbles. Afterwards, the specimens were covered with a thin polyethylene film until the completion of setting. The shaped cylindrical specimens were removed from molds after 24 hours and cured at room temperature $\left(23 \pm 5^{\circ} \mathrm{C}\right)$ for 14, 21 and 28 days. It is followed by a dipping in acetone for 3 days, and by drying at $100^{\circ} \mathrm{C}$ to stop the setting reactions [33].

Table 2. Chemical composition of the crude laterite

\begin{tabular}{cc}
\hline Oxyde & Wt.\% \\
\hline $\mathrm{SiO}_{2}$ & 41.57 \\
\hline $\mathrm{Al}_{2} \mathrm{O}_{3}$ & 28.81 \\
\hline $\mathrm{Fe}_{2} \mathrm{O}_{3}$ & 13.25 \\
\hline $\mathrm{MnO}$ & 0.02 \\
\hline $\mathrm{MgO}$ & 0.03 \\
\hline $\mathrm{CaO}$ & $<\mathrm{DL}$ \\
\hline $\mathrm{Na}_{2} \mathrm{O}$ & $<\mathrm{DL}$ \\
\hline $\mathrm{K}_{2} \mathrm{O}$ & 0.07 \\
\hline $\mathrm{TiO}_{2}$ & 2.03 \\
\hline $\mathrm{P}_{2} \mathrm{O}_{5}$ & 0.26 \\
\hline $\mathrm{L} . \mathrm{O} . \mathrm{I}$ & 13.70 \\
\hline Total & 99.73 \\
\hline
\end{tabular}

Grounded specimens were submitted to X-ray diffraction and Fourier Transform Infrared Spectroscopy (absorbance mode from $4000 \mathrm{~cm}^{-1}$ to $400 \mathrm{~cm}^{-1}$ ). Compressive strength of both dry and wet specimens (dipped in water for 24 hours) were measured with a Hydro-Electric device (M\&O, type $11.50, \mathrm{~N}^{\circ} 21$ ), which operates at the rate of $3 \mathrm{~mm} / \mathrm{min}^{-1}$. Reported results are averaged from 5 specimens. The setting times of fresh pastes were measured with a Vicat apparatus, according to the EN 196-3 standard.

\section{RESULTS}

\subsection{Characteristics of raw materials}

According to the chemical composition of the $\mathrm{LN}$ laterite (Table 2 and Eq. 1), the degree of laterization is $\mathrm{R}=1.90$. It is therefore classified as a clayey laterite in which kaolinite mineral has a well-ordered structure. It is from the initial stage of the geological formation process of laterite [24, 34]. The sum of $\mathrm{SiO}_{2}$ and $\mathrm{Al}_{2} \mathrm{O}_{3}$ oxides is 70.38 wt.\%, and it is known that the interaction of these two oxides is predominant during the formation of the geopolymer microstructure [11, 35].

From Figure 1, the TG curve shows three mass losses that are correlated with DTA phenomena. The peak temperatures of mass losses are: $65^{\circ} \mathrm{C}$ for the departure of free water, $270^{\circ} \mathrm{C}$ referring to the dehydroxylation of the iron aluminum oxide hydroxide $(\mathrm{Fe}(0.93 \mathrm{Al} 0.07) \mathrm{O}(\mathrm{OH}))$ that is identified by XRD (Figure 2). This compound is a modified goethite and might undergoes a similar thermal transformation than that of lepidocrocite [36], according to Eq. (2):

$$
2 \mathrm{Fe}(0.93 \mathrm{Al} 0.07) \mathrm{O}(\mathrm{OH}) \rightarrow \gamma\left(\mathrm{Fe}(0.93 \mathrm{Al} 0.07)_{2} \mathrm{O}_{3}+\mathrm{H}_{2}(2)\right.
$$

At $525^{\circ} \mathrm{C}$ the typical kaolinite dehydroxylation occurs [37, 38], according to Eq. (3):

$$
2 \mathrm{SiO}_{2}, \mathrm{Al}_{2} \mathrm{O}_{3} 2 \mathrm{H}_{2} \mathrm{O} \rightarrow 2 \mathrm{SiO}_{2}, \mathrm{Al}_{2} \mathrm{O}_{3}+2 \mathrm{H}_{2} \mathrm{O}
$$

where, kaolinite is transformed into the high temperature form, with a very low crystallinity degree and a high reactivity. The relative importance of this reaction must be considered since 
kaolinite content is about $51.52 \mathrm{wt} . \%$ in the initial raw material (LN).

Another endothermic peak is observed at about $575^{\circ} \mathrm{C}$ that corresponds to the allotropic transformation of quartz $\alpha$ to quartz $\beta$. X-ray diffraction patterns (Figure 2) also reveal the existence of non-clay minerals, namely quartz and anatase that don't undergo thermal transformations within the same temperature range.

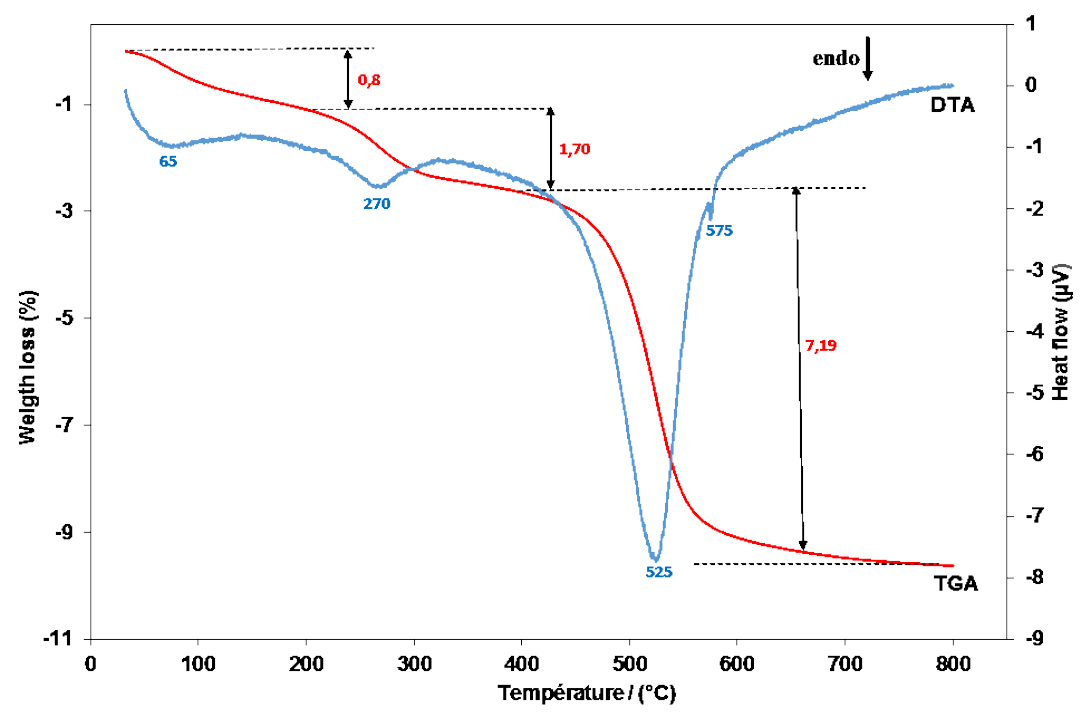

Figure 1. Thermal analysis of laterite (LN)

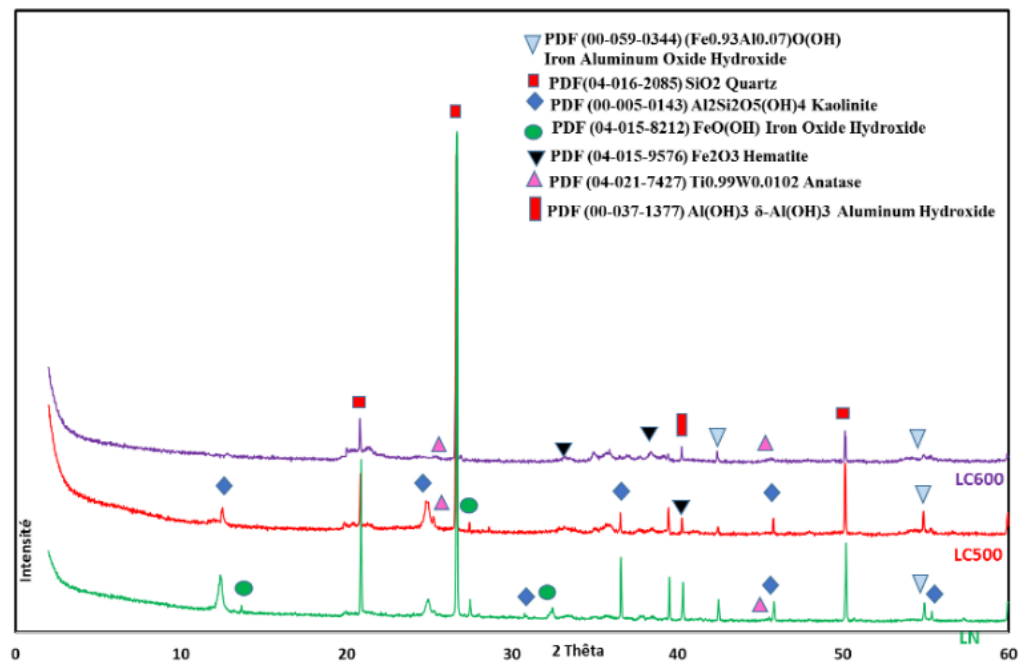

Figure 2. XRD patterns of lateritic (LN) and calcinate laterites (L500 and L600)

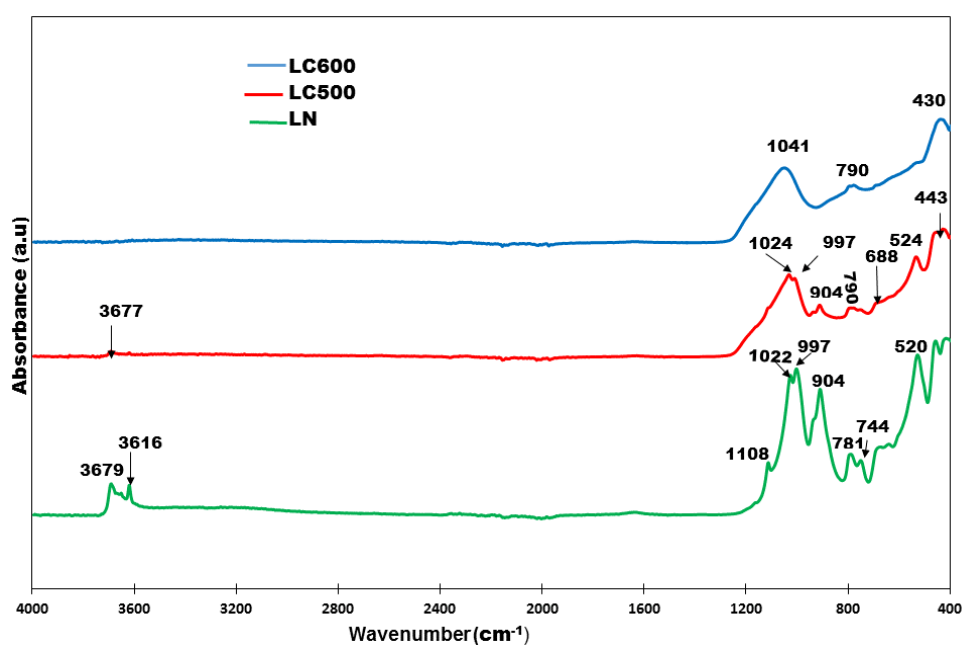

Figure 3. FTIR spectra of LN, L500 and L600 
A weak hump in the $2 \Theta$ range of $20-28^{\circ}$ in the $\mathrm{LN}$ laterite pattern is similar to that of the heat-treated materials LN500 and LN600, that is from the presence of amorphous phases. For laterite, the amorphous phase is both a disorganized silicoaluminate structure and an amorphous alumina hydroxide. For alumina hydroxide, its amount would be $8.44 \mathrm{wt} . \%$ of the whole alumina content that is not from kaolinite. When temperature of the thermal treatment increases from 500 to $600^{\circ} \mathrm{C}$, the high intensity and sharp peaks from crystallized phases are vanished, and the remaining background variations reveal the predominance of an amorphous phase.

BET specific surfaces are $26.30 \mathrm{~m}^{2} \mathrm{~g}^{-1}$ for $\mathrm{LN}, 29.14 \mathrm{~m}^{2} \mathrm{~g}^{-1}$ for LN500, and $20.30 \mathrm{~m}^{2} \mathrm{~g}^{-1}$ for LN600. It is a very important property since it is related to the reactivity with time of powders mixed with the alkaline solution. The reactivity of mixtures is also related to the nature and content of different minerals as well as their size distributions [38, 39]. Particularly, the role of iron containing mineral phases was also evidenced in previous studies [25, 27, 40, 41].

FTIR analysis (Figure 3) also support the observations made from XRD patterns, indicating the presence of kaolinite in $\mathrm{LN}$ and LN500, but not in LN600. Instead of the four typical absorption bands of $\mathrm{OH}$, which are from kaolinite, only three of them are shown on the spectra of LN and L500; at 3679 and $3677 \mathrm{~cm}^{-1}$ for the $\mathrm{OH}$ stretching and at $3616 \mathrm{~cm}^{-1}$ for the $\mathrm{Al}-$ $\mathrm{O}-\mathrm{H}$ stretching. Other bands related to kaolinite are at 1108 $\mathrm{cm}^{-1}$ (apical Si-O), 1022 and $997 \mathrm{~cm}^{-1}$ (Si-O-Si in plane), and $904 \mathrm{~cm}^{-1}$ for the stretching vibration of $\mathrm{OH}$ groups. All bands of kaolinite are vanished in LN600 spectrum. However, a remaining band at $1041 \mathrm{~cm}^{-1}$ is from the asymmetrical vibration of $\mathrm{Si}-\mathrm{O}-\mathrm{Al}$ in metakaolinite and from the symmetrical elongation of $\mathrm{Si}-\mathrm{O}-\mathrm{Si}$ that is most likely attributed to quartz or to the $\mathrm{Si}-\mathrm{O}$ stretching of the unreacted kaolinite [42]. For all samples, Si-O vibrations at 790, 781, 744,688 and $453 \mathrm{~cm}^{-1}$ are attributed to quartz. Iron species are identified with bands at $524,520,453 \mathrm{~cm}^{-1}$ that are related to $\mathrm{Fe}-\mathrm{O}$ stretching $[42,43]$.

\subsection{Characteristics of activated materials}

\subsubsection{Chemical and mineralogical phases}

The XRD patterns of Figure 4 a-b for the dried pastes of activated materials evidence the presence of phases that are the same than that in initial materials LN, LN500 and LN600. With LN500, the partial substitution of laterite leads to the increase of kaolinite peaks. With LN600, kaolinite peaks decrease with the amount of the substituted fractions. It evidences that mostly heat-treated aluminosilicates components are involved in geopolymerization whereas unreactive minerals act as fillers.

The contribution of these phases in the aspect and texture of specimens after 24 hours of curing is seen in photos of Figure $5 \mathrm{a}-\mathrm{b}$. A consolidated texture is evidenced with all samples, and the homogeneous red color can be referred to the $10 \mathrm{R} 4 / 8$ Munsel Code [44].
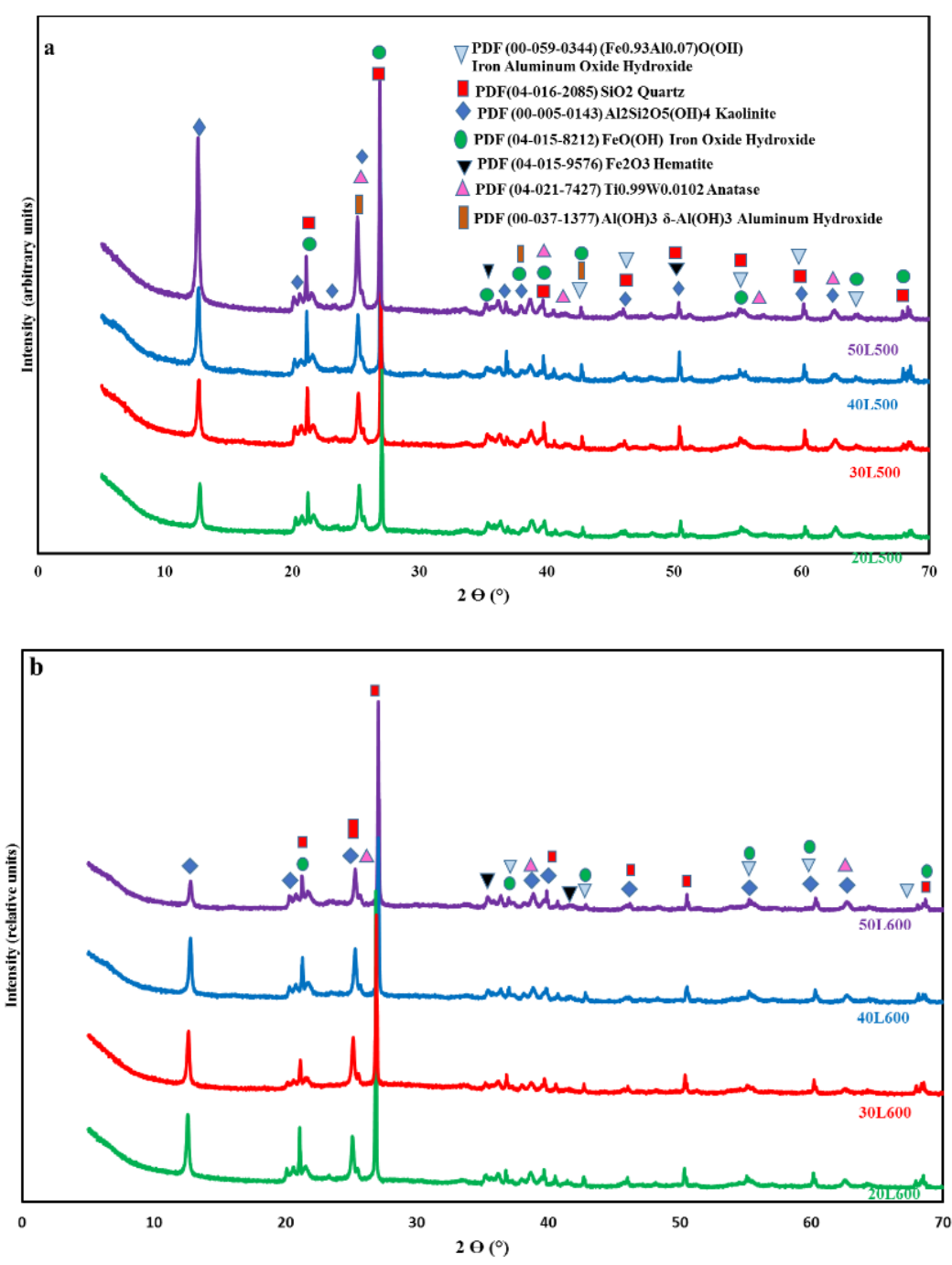

Figure 4. XRD pattern of geopolymer (a) LN500 (b) LN600) 


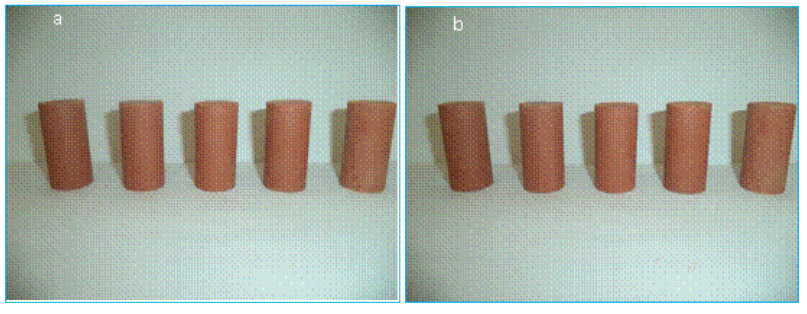

Figure 5. Photos of geopolymers specimens issued from (a) L500 and (b) L600

In Figure 6 a-b, FTIR spectra exhibit absorption bands at $1645 / 1650 \mathrm{~cm}^{-1}$ and $1388 / 1392$ corresponding to the bending and stretching vibrations of $\mathrm{H}-\mathrm{O}-\mathrm{H}$ bonds of water molecules, which has been absorbed or entrapped in the large cavities of the polymeric framework [35, 45, 46]. The absorption bands around $1400 \mathrm{~cm}^{-1}$ is from the stretching vibrations of $\mathrm{C}-\mathrm{O}$ bonds of sodium carbonate, probably issued from efflorescence [46]. Two characteristic bands of kaolinite are observed at $3685 / 3658$ and $3612 / 3606 \mathrm{~cm}^{-1}$ indicating the presence of a small quantity of kaolinite, that remains after the reaction process with alkaline solutions. They are in the interval of $997-1041 \mathrm{~cm}^{-1}$ and are attributed to the symmetric stretching vibration of $\mathrm{Si}-\mathrm{O}-\mathrm{Si}$ and/or $\mathrm{Si}-\mathrm{O}-\mathrm{Al}$ and $\mathrm{Si}-\mathrm{O}-\mathrm{Fe}$ of the geopolymer gel. Bands near $412 \mathrm{~cm}^{-1}$ are the indication of the presence of ferrosialates $\mathrm{Fe}-\mathrm{O}-\mathrm{Si}(\mathrm{Al})$ issued from the dissolution of iron oxide in the alkaline solution. It contributes to the polycondensation process leading to geopolymer gel [11, 27].
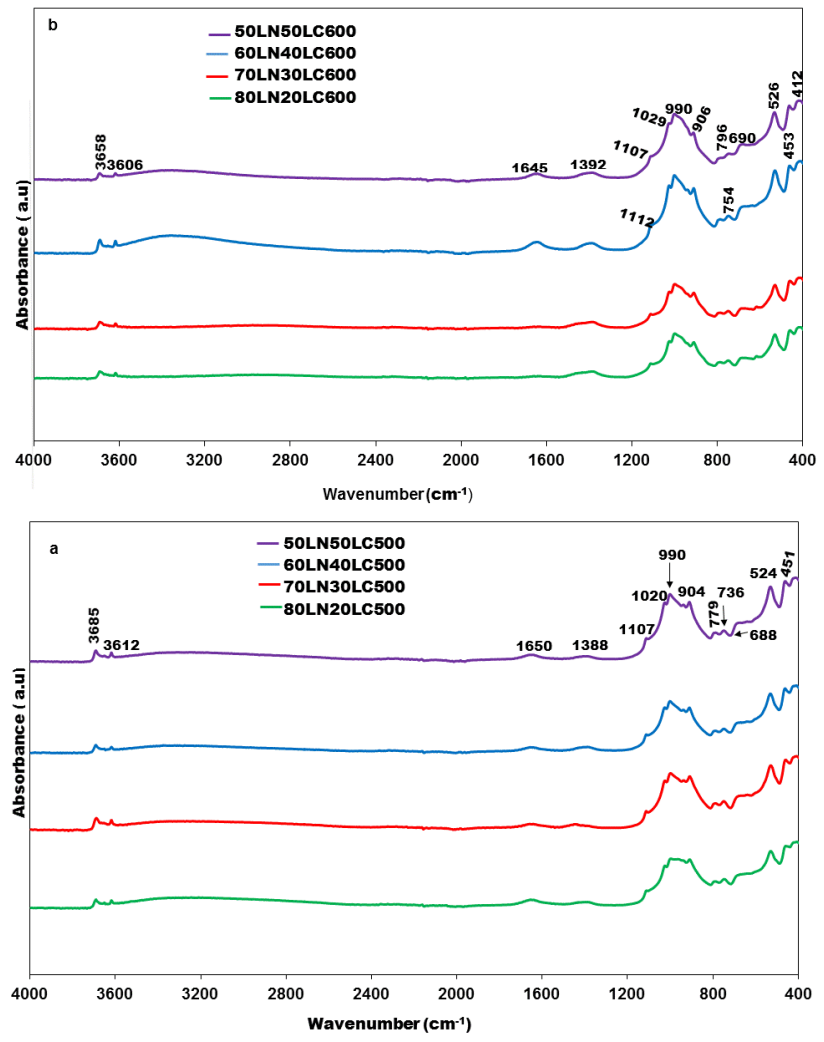

Figure 6. FTIR spectra of geopolymers (a) L500, (b): LN600)

\subsubsection{Physical and mechanical properties}

Figure 7 evidences the longer initial setting time of synthesized geopolymer, in comparison to that of Portland cement (approximately $45 \mathrm{~min}$ ). However, the measurement of consistency after 1440 min of curing for the samples with $80 \mathrm{wt} \%$ of LN and $20 \mathrm{wt} \%$ of LN500 (Figure $5 \mathrm{a}-\mathrm{b}$ ) proves that the initial setting time occurs before 24 hours. In general, the setting time decrease with the increase of the amount of heat-treated laterite.

The curing process with time is correlated with the variation of the mechanical strengths after 28 days that were obtained with test-discs and from different compositions. They are in Figure 8a for LN500 and in Figure 8b for LN600. Mechanical strength of LN500 attains the maximum value of $2.95 \mathrm{MPa}$ for a composition of $50 \mathrm{wt} \%$ of $\mathrm{LN}$ and $50 \mathrm{wt} \%$ of LN500. A higher strength of $17 \mathrm{MPa}$ is obtained with $50 \mathrm{wt} \%$ of $\mathrm{LN}$ and $50 \mathrm{wt} \%$ of LN600 sample.

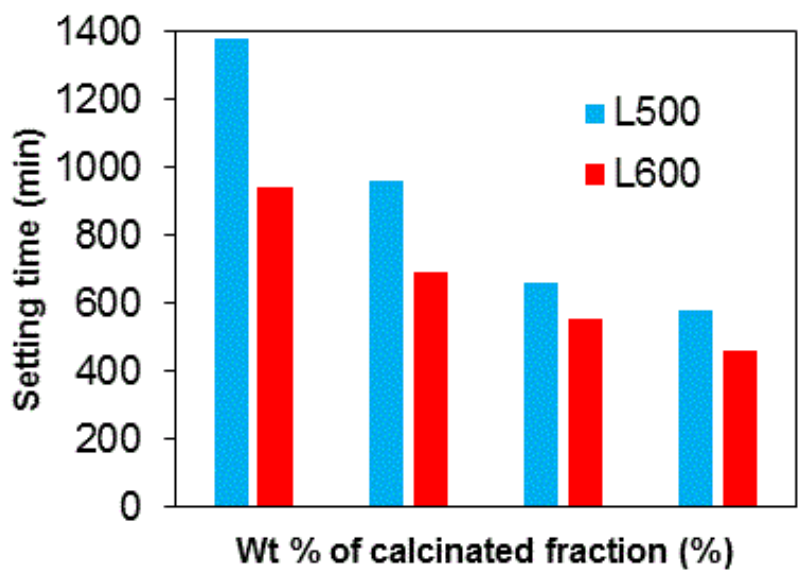

Figure 7. Setting time of geopolymers (a) LN500; (b) LN600
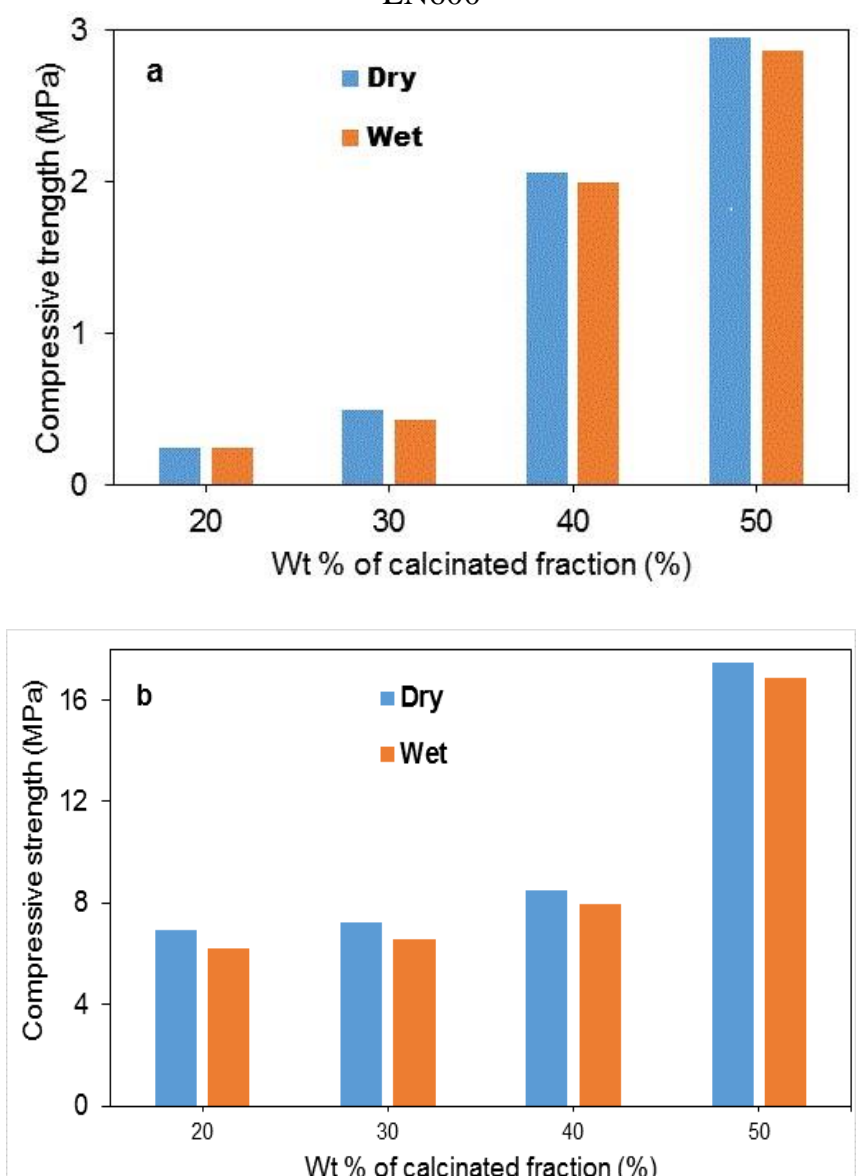

Figure 8. Dry and wet compressive strength of geopolymers after 28 days (a) LN500; (b) LN600 


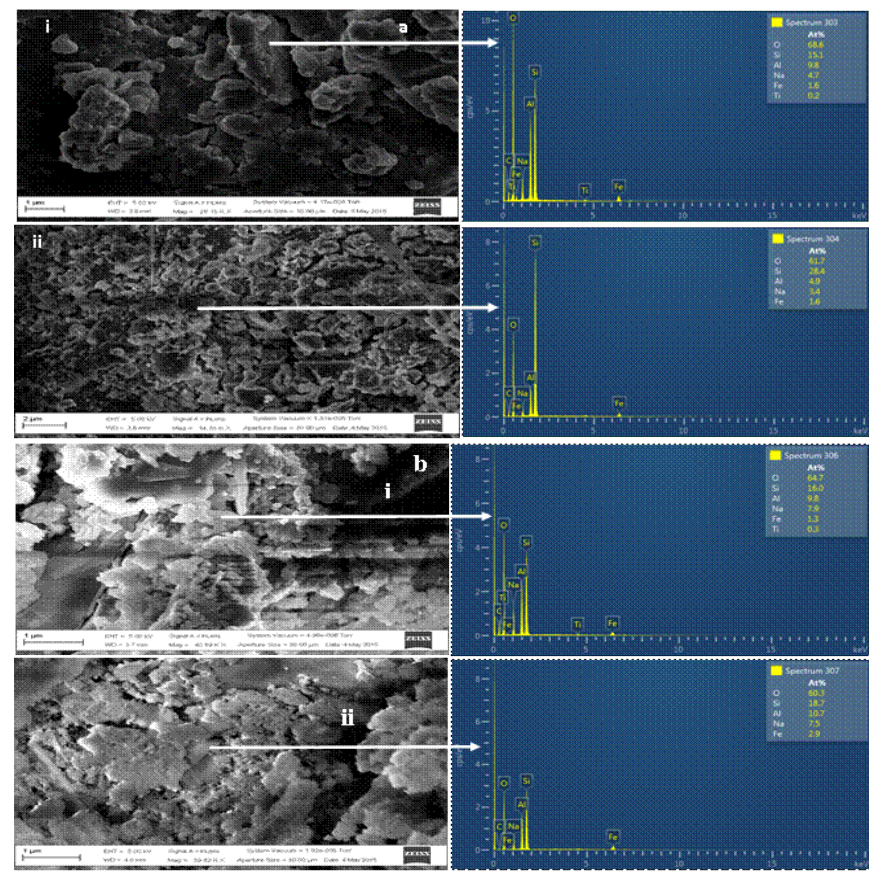

Figure 9. a-b SEM/EDS images of geopolymer (ai) LN20L500, (aii) LN50L500, (bi): LN20L600, (bii): LN50L600)

The SEM/EDS images of two different compositions (80 wt $\%$ of LN and $20 \mathrm{wt} \%$ of LN500, $50 \mathrm{wt} \%$ of LN and $50 \mathrm{wt} \%$ of LN500) and (80 wt \% of LN and $20 \mathrm{wt} \%$ of LN600, $50 \mathrm{wt} \%$ of LN and $50 \mathrm{wt} \%$ of LN600) are in Figs. 9 a-b respectively. Whatever the composition, images evidence a compact but heterogeneous matrix where dense grains are randomly distributed. Chemical investigations using EDS of coarse particles evidence the occurrence of mostly aluminosilicates phases, iron minerals and quartz. Identified phases are the same than that identified by XRD and FTIR, since they are from unreacted particles whose existence is supposed to favor the consolidation of a tridimensional network in the matrix phase of the geopolymer.

\section{DISCUSSION}

For the two series of mixtures with laterite mixed to 0-50 wt $\%$ of the heat-treated laterites at 500 and $600{ }^{\circ} \mathrm{C}$, the alkaline activation process appears to be mostly controlled by the ratio of the heat-treated fractions of laterite. This behavior is similar to that of mixtures containing metakaolin. Particularly, it has been proved that metakaolin obtained by the thermal dehydroxylation of kaolinite has a low crystallinity degree, favoring a high availability of $\mathrm{Si}^{4+}$ and $\mathrm{Al}^{3+}$ ions, and promoting the reactions with alkaline solutions. During dissolution, the environment and coordination number of structural Al are changed, reducing the cohesion between layers. Internal surfaces of phyllosilicate layers become accessible to reactions. It means that silica tetrahedral units become available for the polycondensation reactions. $\mathrm{SiO}_{4}$ and $\mathrm{AlO}_{4}^{-}$units are able to form a new network where the negative charge of IV-fold coordinated $\mathrm{Al}^{3+}$ is balanced by the positive charges of $\mathrm{Na}^{+}$ions from the alkaline solution $[47,11]$. The reaction process leads to the formation of a geopolymer gel that acts as the matrix phase, which bind unreacted particles, forming a composite geopolymer material. With the control of the $\mathrm{Si} / \mathrm{Al}$ ratio during the reaction sequence, all properties in use of geopolymer products can be optimized, such as the mechanical strength, the workability, and the resistance to adverse environmental conditions.

In this study, it is seen that the geopolymerization process differs to some extend to that issued from laterite metakaolinite mixtures. With heat treated laterite, we evidence the role of iron species from laterite (13.25 wt\% of $\mathrm{Fe}_{2} \mathrm{O}_{3}$ ). It promotes the formation of a geopolymer structural network, as already studied in previous works [19, 39, 11, 27].

Similarly, to the behavior of $\mathrm{Al}^{3+}$ during dissolution in the alkaline solution, this study evidences that $\mathrm{Fe}^{3+}$ has an important role in the sequence of reactions during the formation of the geopolymer gel. It was discussed by Davidovits [48] describing the formation of small clusters of ferrosialate geopolymer, from both $(\mathrm{Al}-\mathrm{Fe}) \mathrm{O}_{4}$ and $\mathrm{SiO}_{4}$ structural units.

The typical microstructures of materials are shown in SEM images of Figure 9a and Figure 9b. They evidence the heterogeneous characteristics of all microstructures. The unreacted particles of kaolinite and other mineral phases are coarse aggregates that are randomly distributed in the matrix phase. Since materials present a dense texture, it proves that amorphous phases from heat treated laterites promote the geopolymerization.

Using the heat-treated laterite LN600, the compressive strength is higher than that of specimens with LN500. Simultaneously, the setting time is shortened, favoring the geopolymer hardening. However, it is in contrast with BET specific surface areas of raw aluminosilicate powders that are $29.14 \mathrm{~m}^{2} \mathrm{~g}^{-1}$ for LN500, $26.30 \mathrm{~m}^{2} \mathrm{~g}^{-1}$ for $\mathrm{LN}$, and $20.30 \mathrm{~m}^{2} \mathrm{~g}^{-1}$ for LN600. Since LN500 exhibits the highest value of SSA, but having the lowest reactivity, the role of iron species can be pointed out. It is known that iron has an important role in the structural characteristics of kaolinite changing the dehydroxylation and structural reorganization processes [49]. Considering the reaction sequence leading to geopolymerization, it appears that both the rate and extend of dissolution and polycondensation processes are changed in the presence of iron.

However, the final material has still a composite microstructure with a matrix phase having a gel structure where coarse aggregates of unreacted phases are distributed. Their quantities and distribution are parameters that favor the optimization of material properties [50,51]. Since larger zones of the matrix phase are detrimental to strength, this work show that a limited fraction of a heat-treated laterite must be added (30 wt\% of LN500) to attain a value of $18.25 \mathrm{MPa}$ that meets the standard mechanical strength [52].

\section{CONCLUSION}

The study is devoted to the optimization of a new laterite containing geopolymer that has a low environmental impact. It is also a low-cost manufactured material since local laterite is the major mineral component. The material has a microcomposite microstructure with hard grains that are distributed in a low structurally organized inorganic polymer acting as a matrix phase. The geopolymerization process and the properties (setting time, mechanical strength...) of the matrix phase were improved through the combined action of the raw laterite mixed with a fraction of heat-treated laterite (500- 
$\left.600^{\circ} \mathrm{C}\right)$. In microstructure, the crystallized particles from nonclayed minerals and from aggregates of kaolinite also contribute to strength. However, the kinetic of geopolymerization is changed since the initial phases are not readily dissolved in the alkaline solution.

This study contributes to the reduction of the overall energy consumption during the manufacturing process of building materials. It is obtained by optimizing the quantity of heattreated laterite, to promote a specific setting process via geopolymerization. The obtained geopolymer is expected to be more resistant to repeated cycles in wet and dry climates of tropical countries, in comparison to other building materials with compacted clays and sand. It can be assumed an extensive use as structural materials with a large potential of applications in range of building and civil engineering.

\section{ACKNOWLEDGEMENTS}

Researches were carried out at the University of Pavia, Italy, through the scholarships award of the University Centre for International Co-operation and Development (CICOPS). Experiments were also performed at the University of Zululand, South Africa with the financial support of TWAS, Fellowship for Research and Advanced Training.

\section{REFERENCES}

[1] Trolard, F., Tardy, Y. (1989). A model of Fe ${ }^{3+-}$ kaolinite, $\mathrm{Al}^{3+}$-goethite, $\mathrm{Al}^{3+}$-hematite equilibria in laterites. Clay Minerals, 24(1): 1-21 https://doi.org/10.1180/claymin.1989.024.1.01

[2] Bourgeon, G., Gunnell, Y. (2005). La latérite de Buchanan. Étude et Gestion des Sols, 12(2): 87-100. http://www.afes.fr/publications/revue-etude-et-gestiondes-sols/volume-12-numero-2/

[3] Amalia, N., Riska, A., San, F.P. (2017). The potential of laterite soils deposit south Sulawesi as a precursor for Na-poly (Ferro-Sialate) geopolymers. In MATEC Web of Conferences, 97: 01014. https://doi.org/10.1051/matecconf/20179701014

[4] Touré, P.M., Sambou, V., Faye, M., Thiam, A., Adj, M., Azilinon, D. (2017). Mechanical and hygrothermal properties of compressed stabilized earth bricks (CSEB). Journal of Building Engineering, 13: 266-271. https://doi.org/10.1016/j.jobe.2017.08.012

[5] Habert, G., De Lacaillerie, J.D.E., Roussel, N. (2011). An environmental evaluation of geopolymer based concrete production: reviewing current research trends. Journal of Cleaner Production, 19(11): 1229-1238. https://doi.org/10.1016/j.jclepro.2011.03.012

[6] He, Z.J., Zhu, X.D., Wang, J.J., Mu, M.L., Wang, Y.L. (2019). Comparison of $\mathrm{CO}_{2}$ emissions from OPC and recycled cement production. Construction and Building Materials, 211: 965-973. https://doi.org/10.1016/j.conbuildmat.2019.03.289

[7] Samarakoon, M.H., Ranjith, P.G., Rathnaweera, T.D., Perera, M.S.A. (2019). Recent advances in alkaline cement binders: A review. Journal of Cleaner Production. https://doi.org/10.1016/j.jclepro.2019.04.103

[8] Jos, G.J.O., Greet, J.M., Marilena, M., Jeroen, A.H.W.P. (2015). Trends in global $\mathrm{CO}_{2}$ emissions: Report, The Hague: PBL Netherlands Environmental Assessment
Agency; Ispra: European Commission, Joint Research Centre, 80.

[9] Lahoti, M., Tan, K.H., Yang, E.H. (2019). A critical review of geopolymer properties for structural fireresistance applications. Construction and Building Materials, 221: 514-526. https://doi.org/10.1016/j.conbuildmat.2019.06.076

[10] Pouhet, R., Cyr, M. (2015). Alkali-silica reaction in metakaolin-based geopolymer mortar. Materials and Structures, $\quad 48(3)$ : 571-583. https://doi.org/10.1617/s11527-014-0445-x

[11] Vickers, L., van Riessen, A., Rickard, W.D. (2015). Precursors and additives for geopolymer synthesis. FireResistant Geopolymers, Springer. https://doi.org/10.1007/978-981-287-311-8_2

[12] Almalkawi, A.T., Balchandra, A., Soroushian, P. (2019). Potential of using industrial wastes for production of geopolymer binder as green construction materials. Construction and Building Materials, 220: 516-524. https://doi.org/10.1016/j.conbuildmat.2019.06.054

[13] Hamdi, N., Messaoud, I.B., Srasra, E. (2019). Production of geopolymer binders using clay minerals and industrial wastes. Comptes Rendus Chimie, 22(2-3): 220-226. https://doi.org/10.1016/j.crci.2018.11.010

[14] Li, Z.M., Zhang, S.Z., Zuo, Y.B., Chen, W., Ye, G. (2019). Chemical deformation of metakaolin based geopolymer. Cement and Concrete Research, 120: 108118. https://doi.org/10.1016/j.cemconres.2019.03.017

[15] Koutník, P., Soukup, A., Bezucha, P., Šafář, J., Kohout, J. (2020). Low viscosity metakaolinite based geopolymer binders. Construction and Building Materials, 230: 116978 . https://doi.org/10.1016/j.conbuildmat.2019.116978

[16] Gharzouni, A., Joussein, E., Samet, B., Baklouti, S., Rossignol, S. (2015). Effect of the reactivity of alkaline solution and metakaolin on geopolymer formation. Journal of Non-Crystalline Solids, 410: 127-134. https://doi.org/10.1016/j.jnoncrysol.2014.12.021

[17] Chen, L., Wang, Z.Q., Wang, Y.Y., Feng, J. (2016). Preparation and properties of alkali activated metakaolinbased geopolymer. Materials, 9(9): 767. https://doi.org/10.3390/ma9090767

[18] Hos, J.P., McCormick, P.G., Byrne, L.T. (2002). Investigation of a synthetic aluminosilicate inorganic polymer. Journal of Materials Science, 37(11): 23112316. https://doi.org/10.1023/A:1015329619089

[19] Baenla, J., Mbah, J.B., Ndjock, I.D.L., Elimbi, A. (2019). Partial replacement of low reactive volcanic ash by cassava peel ash in the synthesis of volcanic ash based geopolymer. Construction and Building Materials, 227: 116689. https://doi.org/10.1016/j.conbuildmat.2019.116689

[20] Tchakoute, H.K., Elimbi, A., Yanne, E., Djangang, C.N. (2013). Utilization of volcanic ashes for the production of geopolymers cured at ambient temperature. Cement and Concrete Composites, 38: 75-81. https://doi.org/10.1016/j.cemconcomp.2013.03.010

[21] Bondar, D., Lynsdale, C.J., Milestone, N.B., Hassani, N., Ramezanianpour, A.A. (2011). Effect of type, form, and dosage of activators on strength of alkali-activated natural pozzolans. Cement and Concrete Composites, 33(2): $251-260$ https://doi.org/10.1016/j.cemconcomp.2010.10.021

[22] Djobo, J.Y., Tchadjié, L.N., Tchakoute, H.K., Kenne, 
B.B.D., Elimbi, A., Njopwouo, D. (2014). Synthesis of geopolymer composites from a mixture of volcanic scoria and metakaolin. Journal of Asian Ceramic $\begin{array}{lll}\text { Societies, } & \text { 2(4): }\end{array}$ https://doi.org/10.1016/j.jascer.2014.08.003

[23] Lee, N.K., Lee, H.K. (2015). Reactivity and reaction products of alkali-activated, fly ash/slag paste. Construction and Building Materials, 81: 303-312. https://doi.org/10.1016/j.conbuildmat.2015.02.022

[24] Nkwaju, R.Y., Djobo, J.N.Y., Nouping, J.N.F., Huisken, P.W.M., Deutou, J.G.N., Courard, L. (2019). Iron-rich laterite-bagasse fibers based geopolymer composite: Mechanical, durability and insulating properties. Applied Clay Science, 183 : 105333. https://doi.org/10.1016/j.clay.2019.105333

[25] Obonyo, E., Kamseu, E., Lemougna, P., Tchamba, A., Melo, U., Leonelli, C. (2014). A sustainable approach for the geopolymerization of natural iron-rich aluminosilicate materials. Sustainability, 6(9): 55355553. https://doi.org/10.3390/su6095535

[26] Lemougna, P.N., Madi, A.B., Kamseu, E., Melo, U.C., Delplancke, M.P., Rahier, H. (2014). Influence of the processing temperature on the compressive strength of $\mathrm{Na}$ activated lateritic soil for building applications. Construction and Building Materials, 65: 60-66. https://doi.org/10.3390/su6095535

[27] Kaze, R.C., Moungam, L.B., Djouka, M.F., Nana, A., Kamseu, E., Melo, U.C., Leonelli, C. (2017). The corrosion of kaolinite by iron minerals and the effects on geopolymerization. Applied Clay Science, 138: 48-62. https://doi.org/10.1016/j.clay.2016.12.040

[28] Ndjigui, P.D., Badinane, M.F.B., Nyeck, B., Nandjip, H.P.K., Bilong, P. (2013). Mineralogical and geochemical features of the coarse saprolite developed on orthogneiss in the SW of Yaoundé, South Cameroon. Journal of African Earth Sciences, 79: 125-142. https://doi.org/10.1016/j.jafrearsci.2012.11.008

[29] Ngon, G., Yongue, R., Bitom, D., Bilong, P. (2009). A geological study of clayey laterite and clayey hydromorphic material of the region of Yaoundé (Cameroon): a prerequisite for local material promotion. Journal of African Earth Sciences, 55: 69-78. https://doi.org/10.1016/j.jafrearsci.2008.12.008

[30] Mbumbia, L., de Wilmars, A.M., Tirlocq, J. (2000). Performance characteristics of lateritic soil bricks fired at low temperatures: A case study of Cameroon. Construction and Building Materials, 14(3): 121-131. https://doi.org/10.1016/S0950-0618(00)00024-6

[31] Król, M., Rożek, P. (2018). The effect of calcination temperature on metakaolin structure for the synthesis of zeolitesMagdalena Król and Piotr Rożek Effect of calcination temperature on metakaolin structure. Clay Minerals, 53(4):

657-663. https://doi.org/10.1180/clm.2018.49

[32] Ndiaye, M. (2013). Contribution à l'étude de sols latéritiques du Sénégal et du Brésil, Thèse de Doctoral, Université Paris Est, .France.

[33] Ishwarya, G., Singh, B., Deshwal, S., Bhattacharyya, S.K. (2019). Effect of sodium carbonate/sodium silicate activator on the rheology, geopolymerization and strength of fly ash/slag geopolymer pastes. Cement and Concrete Composites, 97: 226-238. https://doi.org/10.1016/j.cemconcomp.2018.12.007

[34] Ambrosi, J.P., Nahon, D., Herbillon, A.J. (1986). The epigenetic replacement of kaolinite by hematite in laterite-petrographic evidence and the mechanisms involved. Geoderma, 37(4): 283-294. https://doi.org/10.1016/0016-7061(86)90030-3

[35] Barbosa, V.F, MacKenzie, K.J., Thaumaturgo, C. (2000). Synthesis and characterisation of materials based on inorganic polymers of alumina and silica: sodium polysialate polymers. International Journal of Inorganic Materials, 2(4): 309-317. https://doi.org/10.1016/S14666049(00)00041-6

[36] Song, X.W., Boily, J.F. (2016). Surface and bulk thermal dehydroxylation of FeOOH polymorphs. The Journal of Physical Chemistry A, 120(31): 6249-6257. https://doi.org/10.1021/acs.jpca.6b04294

[37] Jouenne, C.A. (2001). Traité de céramiques et matériaux minéraux. Septima. Paris, France.

[38] Boussois, K., Tessier-Doyen, N., Blanchart, P. (2013). Anisotropic kinetic of the kaolinite to mullite reaction sequence in multilayer ceramics. Journal of the European Ceramic Society, 33(2): 243-249. https://doi.org/10.1016/j.jeurceramsoc.2012.08.014

[39] Wilson, M.J., Wilson, L., Patey, I. (2014). The influence of individual clay minerals on formation damage of reservoir sandstones: a critical review with some new insights. Clay Minerals, 49(2): 147-164. https://doi.org/10.1180/claymin.2014.049.2.02

[40] Provis, J.L., Palomo, A., Shi, C. (2015). Advances in understanding alkali-activated materials. Cement and Concrete Research, 78: 110-125. https://doi.org/10.1016/j.cemconres.2015.04.013

[41] Soro, N.S., Blanchart, P., Bonnet, J.P., Gaillard, J.M., Huger, M., Touré, A. (2005). Sintering of kaolin in presence of ferric compound: Study by ultrasonic echography. In Journal de Physique IV (Proceedings), 123: 131-135. https://doi.org/10.1051/jp4:2005123022

[42] El Hafid, K., Hajjaji, M. (2015). Effects of the experimental factors on the microstructure and the properties of cured alkali-activated heated clay. Applied Clay Science, 116: 202-210. https://doi.org/10.1016/j.clay.2015.03.015

[43] Saikia, B.J., Parthasarathy, G. (2010). Fourier transform infrared spectroscopic characterization of kaolinite from Assam and Meghalaya, Northeastern India. Journal of Modern Physics, 206. https://doi.org/10.4236/jmp.2010.14031

[44] Cheng, H., Yang, J., Liu, Q., Zhang, J., Frost, R.L. (2010). A spectroscopic comparison of selected Chinese kaolinite, coal bearing kaolinite and halloysite-A midinfrared and near-infrared study. Spectrochimica Acta Part A: Molecular and Biomolecular Spectroscopy, 77(4): 856-861. https://doi.org/10.1016/j.saa.2010.08.018

[45] Nickerson, D. (1976). Munsell Color System, Company, and Foundation. Color Research and Application, 1.

[46] Fernández-Jiménez, A., Palomo, A. (2005). Composition and microstructure of alkali activated fly ash binder: Effect of the activator. Cement and Concrete Research, 35(10): 1984-1992. https://doi.org/10.1016/j.cemconres.2005.03.003

[47] Wattimena, O.K., Antoni, Hardjito, D. (2017). A review on the effect of fly ash characteristics and their variations on the synthesis of fly ash based geopolymer. AIP Conference Proceedings, 1887: 020041-1-12. https://doi.org/10.1063/1.5003524

[48] Davidovits, F., Davidovits, J., Davidovits, M., 
Davidovits, R. (2012). Geopolymer cement of the calcium ferro-aluminosilicate polymer type and production process. Patent No. WO/2012, 56125.

[49] Soro, N., Aldon, L., Fourcade, O., Jumas, J., Laval, J.C., Blanchart, P. (2003). Role of iron in mullite formation from kaolins by Mössbauer spectroscopy and Rietveld refinement. Journal of the American Ceramic Society, 86(1): $\quad 129-134 . \quad$ https://doi.org/10.1111/j.11512916.2003.tb03289.x

[50] Kamseu, E., Lancellotti, I., Sglavo, V., Modolo, L., Leonelli, C. (2016). Design of inorganic polymer mortar from ferricalsialic and calsialic slags for indoor humidity control. Materials, $4(6)$ : 410. https://doi.org/10.3390/ma9060410

[51] Djangang, C.N., Tealdi, C., Cattaneo, A.S., Mustarelli, P., Kamseu, E., Leonelli, C. (2015). Cold-setting refractory composites from cordierite and mullite-cordierite design with geopolymer paste as binder: Thermal behavior and phase evolution. Materials Chemistry and Physics, 154: 66-77.

https://doi.org/10.1016/j.matchemphys.2015.01.046

[52] ASTM D6684 - 18. (2018). Standard Specification for Materials and Manufacture of Articulating Concrete Block (ACB) Systems. ASTM International, West Conshohocken, PA. https://doi.org/10.1520/D6684-18

\section{NOMENCLATURE}

ICDD International Centre for Diffraction Data

EDS

ICDD

EDS

${ }^{\circ} \mathrm{C}$

ICP

OPC

PVC

\begin{tabular}{|c|c|}
\hline $\mathrm{wt} \%$ & Weight percentage \\
\hline$\%$ & Percentage \\
\hline $\mathrm{H}$ & Hour \\
\hline Vol. $\%$ & Volume percentage \\
\hline M & $\operatorname{Molar}(\mathrm{mol} / \mathrm{L})$ \\
\hline g & Gram \\
\hline $\mathrm{MPa}$ & Mega Pascal \\
\hline$\mu \mathrm{m}$ & Micrometer \\
\hline TGA & Thermal Gravimetric Analysis \\
\hline DTA & Differential Thermal Analysis \\
\hline FTIR & Fourier Infrared spectroscopy \\
\hline XRD & X-Ray Diffraction \\
\hline PDF & Powder Diffraction File \\
\hline SEM & Scanning Electron Microscopy \\
\hline SSA & Specific Surface Area in $\mathrm{m}^{2} \mathrm{~g}^{-1}$ \\
\hline Al & Aluminum \\
\hline $\mathrm{Si}$ & Silicone \\
\hline $\mathrm{O}$ & Oxygen \\
\hline $\mathrm{C}$ & Carbon \\
\hline $\mathrm{Fe}_{2} \mathrm{O}_{3}$ & Iron oxide \\
\hline $\mathrm{Al}_{2} \mathrm{O}_{3}$ & Aluminum oxide \\
\hline $\mathrm{SiO}_{2}$ & Siliceous oxide \\
\hline $\mathrm{H}_{2} \mathrm{O}$ & Water \\
\hline $\mathrm{CO}_{2}$ & Carbon dioxide \\
\hline $\mathrm{NaOH}$ & Sodium Hydroxide \\
\hline $\mathrm{EN}$ & European Standard \\
\hline LN & Crude laterite \\
\hline LN500 & Heat treated laterite at $500^{\circ} \mathrm{C}$ \\
\hline LN600 & Heat treated laterite at $600^{\circ} \mathrm{C}$ \\
\hline 80LN20L500 & Mixture of $80 \% \mathrm{LN}$ and $20 \%$ L500 \\
\hline 50LN50L600 & Mixture of $50 \% \mathrm{LN}$ and $50 \% \mathrm{~L} 600$ \\
\hline 50LN50L500 & Mixture of $50 \% \mathrm{LN}$ and $50 \% \mathrm{~L} 500$ \\
\hline 80LN20L600 & Mixture of $80 \% \mathrm{LN}$ and $20 \% \mathrm{~L} 600$ \\
\hline $2 \mathrm{SiO}_{2} \cdot \mathrm{Al}_{2} \mathrm{O}_{3} \cdot 2 \mathrm{H}_{2}$ & Chemical formulae of kaolinite \\
\hline $2 \mathrm{SiO}_{2} \cdot \mathrm{Al}_{2} \mathrm{O}_{3}$ & Chemical formulae of metakaolinte \\
\hline $\mathrm{H}-\mathrm{N}-\mathrm{A}-\mathrm{S}$ & Sodium aluminosilicate hydrate \\
\hline
\end{tabular}

